\author{
Aksiutina T. V., \\ English Lecturer at the Department of Foreign Languages for Humanities \\ Oles Honchar Dnipro National University \\ Aleksieiev V.S., \\ English Lecturer at the Department of Foreign Languages for Humanities \\ Oles Honchar Dnipro National University
}

\title{
ANALYSING AND HANDLING EHNOCULTURAL LACUNAS IN CROSS-CULTURAL COMMUNICATION
}

Summary. Taking into account the theoretical vision of researches, the article addresses the concept of ethnocultural stereotype, presented as a cultural dominant existing in the minds of its carriers with a mental picture possessing distinctive properties, a certain well-established, invariant, national-cultural specific concept of an object or situation, which forms the national-cultural environment as well as the specifics of the speech activity of its representatives. The reflection features of national culture in stereotypes are analyzed.

The article shows that in the process of perceiving ethno-specific cultural stereotypes people form different attitude towards them. Basically, they are perceived as something alien, because, when discovering a new culture, the recipient evaluates them through the prism of cultural norms and values accepted in his native linguosocial society, which is due to the characteristics of each language. Mismatches and differences in perceiving the surrounding world by speakers of different languages cause a cultural clash. The clash of stereotypes characteristic of different cultures (cultural conflict) can arise misunderstanding in communication, and cause a "cultural shock".

The article focuses on a special type of stereotypes, reflecting social processes, cultural traditions and ethnic traits typical of a certain nation. Defined as ethnocultural lacunas, they fix a number of "gaps" in language and culture of different communities. In the process of intercultural communication, the "images" of cultures that carry invariant and variant components are compared and/or accepted, or repelled, which makes it difficult for the communicators to understand one another, and requires additional interpretation. The study focuses on functioning of culturally specific lacunas in interlanguage discourse and related semantic gaps in the conceptosphere of communicants, thus identifying ways to overcome misunderstandings in linguistic and cultural experiences of interlanguage communities.

Key words: stereotype, national character, intercultural communication, ethnocultural lacunas, cultural shock.

Introduction. Cross-cultural studies have shed the light on a significant role stereotyping plays in intercultural communication $[2 ; 7 ; 10 ; 12 ; 14 ; 19 ; 20 ; 22]$. People in all cultures have shared mental concepts, pictures in their consciousness through which they perceive each other within their own culture and/or typical members of other nations (e.g., the Chinese are industrious, the Latinos are hot-tempered, and the Canadians are docile, compliant). According to Lippmann, "we pick out our culture has already defined for us, and we tend to perceive what we have picked out in the form stereotyped for us by our culture" [20, p. 95]. Stereotypes are an integral element of human consciousness. They include distinctive features, traits, abilities that people may associate with a particular nation. Accumulating a certain standardized collective experience, and, being inspired by the individual in the process of learning and communicating with others, they help him/her navigate his/her life and maintain his/her behavior in a certain way. Without this, Lippmann states, our perception of the world will be like the baby's, "one great, blooming, buzzing confusion" [20, p. 54].

However, our cultural milieu shapes our world outlook in such a way that reality is thought to be objectively perceived through our own cultural pattern, and a differing perception is seen as something incomprehensible, exotic, strange, erroneous or inaccurate, and is, thus, oversimplified. So, many scholars tend to see stereotyping as an attitude related to, or, a function of prejudice, representing a potential obstacle for successful intergroup communication, and therefore, something that should be avoided [18, p. 43].

The aim of the paper. Although we do not, by contrast, consider stereotypes to be good, nevertheless, we suggest regarding stereotypes as concept-systems with positive and negative properties, serving to organize experience as do other concepts. If people recognize and understand differing world views, they will usually adopt a positive and open-minded attitude towards cross-cultural differences. A close-minded view of such differences often results in the maintenance of a stereotype - an oversimplification and blanket assumption. Inspired by the upsurge of the interest in studying the interaction of language, culture, and psychology, the article addresses the notion of "stereotype" in a broad sense - as a concept that includes the ideas of one nation about the culture of another nation as a whole, as a "widely held but fixed and oversimplified image or idea of a particular type of person or thing" [16]. The paper aims to investigate the interaction of the concepts of stereotype and national character, to identify the reflection features of national culture in stereotypes. The research shows that it is the lack of knowledge of systemic characteristics of culture objects that might cause misunderstanding in intercultural communication. In other words, non-congruence in the ethnic-specific images of the consciousness can be regarded as the major factor of cultural clashes inevitably arising in communicants when handling different national beliefs, values, experience. To study the national stereotypes as well as images of the world as a whole created by different nations, the article uses intercultural communication both as an object and as a means of research.

Recent research presentation. For a long time there has been a debate about the definition of the concept of "stereotype"; 
attempts have been made to identify ways of forming and spreading national stereotypes in society, the question of their influence on intercultural relations is discussed, but there is no consensus among researchers regarding the legality of using the word "stereotype" itself $[3 ; 6 ; 7 ; 8 ; 18]$. The term "stereotype" (Greek stereos - solid, typos - imprint) was introduced into scientific circulation by the American sociologist W. Lippman, who understood it as a special form of perception of the world that "imposes a certain character on the data of our senses before the data reach the intelligence" [20,p.54]. Evoked by the outside stimuli, stereotypes make the actual sensation and the preconception occupies consciousness at the same time. "If what we are looking at corresponds successfully with what we anticipated, the stereotype is reinforced for the future, as it is in a man who knows in advance that the Japanese are cunning and has the bad luck to run across two dishonest Japanese" [ibidem, p. 54].

Another sociologist R. Binkley call stereotype the greatest universal denominator. In his opinion, the presence of stereotypes allows the layman to adequately assess the political situation, which is too complicated for his analysis and too remote from his sphere of activity [15, p. 393]. American scientists D. Katz and C. Braille regard the stereotype as a stable idea, which is little consistent with the realities that it seeks to represent, and arise from the inherent person's trait to first determine the phenomenon, and then already observe it [18, p. 288].

In the late 40 s, a large-scale study was conducted to identify how representatives of different cultures perceive each other when communicating; what factors determine their perception. The difference between positive and negative answers has determined the so-called "denominator of friendliness" [18, p. 96].

Until recently, the most comprehensive study of national stereotypes was that of D. Peabody's. Peabody showed that people do hold shared beliefs about national character and that there is consensus across cultures: the French view of Germans is similar to Germans' view of themselves, and vice versa. Despite the possibility of ethnocentric biases, in-group and out-group stereotypes generally agree, at least when characterizing personality traits.

Significant interest in the problems of stereotypes arose in native science in the 90s and early 2000s. Such researches as S.V. Chugrov, A.V. Pavlovskaia, and A.V. Golubev used the concept of "national stereotype," which is, by their definition, a collective perception of one nation about others, as a natural element of national consciousness and international relations. In the core of national images is the socio-historical experience of the nation and its traditions [113]. They directly connected the nature of stereotypes with mythological consciousness, the oldest form of human thinking.

According to A. V. Pavlovskaia, a stereotype is a schematic, one-sided image of a phenomenon, people, country, existing in the human mind and at the same times its assessment, learned even before facing them [7, p. 94]. The historian A.V. Golubev defines a stereotype as a stable, simplified, emotionally colored concept based on group experience, one of the forms of perception of the world. Unfortunately, the early 2000s marked a great decline of interest in the problem of ethnic stereotypes in native science. At the same time the study of the non-congruence of the ethnic-specific images of the consciousness, which in fact reflects the differences in ethnic cultures might shed the light on the reasons of misunderstandings and clashes that arise in cross-cultural communication, and help to achieve successful interaction.
According to native scholars Markovina and Sorokin, the study of ethnic stereotypes should be carried out using the ethnopsycholinguistic Lacuna Theory [8, p. 35-36], since it provides a conceptual framework to identify, describe and interpret differences and similarities in the ways various nations comprehend themselves, other people as well as the whole world. When two cultures come into contact with each other exchanging texts, they inevitably face discrepancies or gaps on the 'semantic map' of a language, text, or cultureas a whole, because eachnation perceives another one through its own local cultural patterns and personal experience. According to Grodzki, we wear cultural glasses "that create a cultural prism once the light of the foreign cultural artifact passes through the lens" [13, p. 112]. These discrepancies (lacunas) presented as ethnic-specific images of the national consciousness arise from the incomplete equivalence of denotative systems in different languages. In a wider context, the term lacuna is used for any "incident in which something exists in one culture but not in another, including values, attitudes, knowledge, experience or expectations" [23]. The "zero equivalence" [13] or non-congruence of concepts denoting both linguistic and cultural specifics in different linguo-cultural communities may provoke astonishment, perplexity, annoyance in intercultural encounters, and even lead to misunderstanding and cross-cultural conflicts conflicts.

Lacunas are divided into four groups: 1) subjective lacunas, reflecting the national and cultural characteristics of communicants in various linguistic and cultural communities; 2) activitycommunicative lacunas, denoting the national-cultural specifics of various activities in their communicative aspect; 3 ) cultural milieu lacunas that consider the process of communication in a broad sense, or lacunae of cultural interior which regard a particular communicative act; 4) textual gaps arising due to the specifics of the text as a communication tool; the specifics of the text can be content, the form of reproduction of the material, the author's poetics [9].

The first group of lacunas is classified as subjective or nationalpsychological lacunas. They arise in a result of mismatches between the national psychological types of communicants, and can be of several kinds. Characterological lacunas are of three types [22]: 1) gaps that reflect the traditional and, to some extent, stereotypical perception of the national character of other people; 2) lacunas, reflecting discrepancies in how similar qualities are manifested among different people; 3) self-reflective lacunas, reflecting how native speakers understand their national character. The existence of characterological lacunas is due to distinctive national features of various local cultures [4]. In the process of intercultural communication certain stereotypes are formed in relation to other cultures, in particular, those that capture the most characteristic features of a particular nation, less manifested in other nations [3]. The main thing in the English national character is believed to be self-restraint, in French - passion, in American - pragmatism, in German - punctuality [7, p. 125]. Punctuality can be seen as a relative characterological gap for the Spaniards and Latin Americans in comparison with speakers of German and Dutch cultures: punctuality is highly valued by Germans and Dutch, but it is of little concern for Spaniards and even less for Latinos [7, p. 126]. All characterological lacunas are relative; when it comes to national character, these universal signs vary in the value system of the corresponding cultures, differing in degree of prevalence. This statement is confirmed by analyzing industriousness as a feature 
inherent in all national characters: you can see the difference between the Americans' industriousness and that of the Germans.

The German industriousness is perceived as thoroughness, accuracy, conscientiousness, discipline, prudence, but without scope and risk [10]. The industriousness of an American is scope, energetic assertiveness, inexhaustible business excitement, initiative [16, p. 97]. Thus, for Americans industriousness in many respects does not coincide with the way the Germans comprehend it: clearly defined organizational skills, the ability to instantly navigate situations typical of Americans are laconic for Germans who equate industriousness to discipline. Self-reflective characterological lacunas reflect the way the representatives of various cultures understand and perceive themselves. For a foreigner, for example, it is difficult to grasp the meaning of the Finnish "sisu", which defines the Finnish national character. The dictionary defines this concept as "a reserve of vitality, endurance, patience, willpower, courage, ingenuity" [8, p. 140]. In life, "sisu" is manifested, according to the Finns themselves, as determination in the face of difficulties; Finn refers to the "sisu" as a reservoir of energy when all other resources are already run out.

Among national psychological lacunas it is worth highlighting "syllogistic" lacunas associated with the national specifics of the "mindset" of the bearers of various cultures. Researchers note more or less significant differences in this area of national psychology [2, p. 83-85]: the philosophical breadth and depth of abstraction are inherent in German thinking, the thinking of the British is the desire not to resort to abstractions [6]; the vivid imagination is characteristic of the French, ideas for them are preferable to facts; on the contrary, the English are distinguished by the restraint of imagination, they focus on facts, numbers, not theories.

Various national-specific thinking patterns can cause the emergence of "mental lacunas", which belong to the second group of activity-communicative gaps. The existence of mental gaps is revealed when the recipient completes the mental tasks that are characteristic of another linguistic and cultural community [5]. These lacunas arise when the speakers of a certain culture are invited to guess a riddle in translation from another language. In this case, the recipients are unable to give the correct answer to the riddle, reflecting the specifics of a foreign culture. So, it breaks the intercultural communication. To generate cross-cultural communication, it is necessary not only to translate texts from one language to another, but also to make them familiar to the native (target language)speaker, in accordance with his/her mentality, to introduce cultural and ethnographic images and symbols traditional for TL. The concept of "behavior" includes a large number of aspects: kinesics (facial expressions, gestures), characteristic of a certain culture; household (everyday) behavior, caused by traditions, customs, lifestyle adopted in this culture, as well as etiquette of communication, a fragment of which is kinesics (kinetic gaps), and everyday behavior (routine gaps) [9]. Kinetic gaps signal the peculiarity of gestural and facial codes of various cultures. The contrastive nature of Ukrainian and German gestures, indicating consent and disagreement ("yes" and "no") is a good example. Kinetic lacunas can be absolute and relative: in Ukrainian culture, for example, there is no such a gesture as knocking at the table with your knuckles as a sign of approval, respect, typical in German culture [10, p. 268]; thus, for the Ukrainians this gesture is an absolute gap; a handshake as a sign of greeting is known in both Ukrainian and English cultures, but in Ukrainian culture it is used much more often than in English, being a relative lacuna for the British [2, p. 157].

The lacunarized character may have a ratio in verbal and nonverbal means in male and female etiquette of communication, which, to some extent, are stereotypes of behavioral characteristic of a particular society [13]. The male type of communication is less flexible, but more dynamic and less focused on the interlocutor. The most common communication genre in men is conversationinformation, and in women is private conversation. Women are more focused on the interlocutor, on dialogue, on a subordinate role in communication, where men choose and change the topic of conversation. On the one hand, society has developed such stereotypes of behavior, according to which a woman plays a subordinate role to a man: she must be a good housewife, able to perform any work; she must be kind, patient, obedient, gentle, loyal, and beautiful. The absence of a husband in this model is seen abnormal, and leaving husband is considered a riot. Language fixes a patriarchal attitude: in it stereotypes are firmly entrenched, according to which many vices are inherent in a woman, therefore, a comparison with her man always carries a negative connotation: talkative, curious, flirty, narcissistic, capricious, hysterical as a woman, female logic; a comparison with a man only decorates a woman: a man's mind, a man's grip, a man's character [12, p. 126].

The subgroup of kinetic lacunas includes mimic lacunas arising from mismatches in the mimic codes that exist in certain cultures. One of the facial expressions is a smile. In different cultures, smiles can, depending on existing etiquette norms, have different iconography and meanings. One of the strange features of the Ukrainian culture in the eyes of the West is gloom, coldness, lack of a smile. Ukrainian people, having fallen into the Englishspeaking world, are perplexed when it comes to smiling. In the view of Ukrainian people, a smile is an integral part of Western culture, inextricably linked to standards of their conduct. In the Western world, a smile is not only a biological reaction to positive emotions; this is a culture-specific sign, a tradition, a custom [14, p. 75]. In American culture, smiling is also a social sign of prosperity. Keep smiling is the motto of the American way of life: "no matter what happens - smile". Pinchbeck optimism in any situation defines American national character, which is officially approved and manifested by all means, including language [22].

A special group of behavioral gaps is made up of "household" ("routine") gaps that define a traditional way of life, habits, and features of everyday life. The British decided to have tea at five o'clock in the evening, but other European nations have no such custom. Many Europeans are surprised that Ukrainians have a bath using a current stream of water, while they themselves collect water into the sink for washing. Consider a stereotype of behavior such as small talk. Dictionaries define it as "meaningless, secular conversation" [1]; "chatter, a light or casual talk"; "a polite conversation about unimportant things" [24, p. 1275]; "conversation on everyday and insignificant secular topics" [16]. The ability to choose the right ones for a conversation is very important when communicating in different linguistic and cultural community. "Safe" conversation topics that are considered suitable for speaking with non-natives vary. Recommended topics for a small talk in English-speaking countries are as follows: travel, weather, work (but not salary and other similar issues related to money), origin, hobbies, hobbies, as well as news, but not related to politics. As 
for those that should be avoided in the conversation, Americans say it's dangerous to talk about two things: politics and religion. In England, similar issues include the following issues: royal family, racial relations, salary / income, health, pets and Northern Ireland [10]. In Ukraine, many of these topics are most popular with even sophisticated people when they get together for any reason.

Conclusion. So, various etiquette norms might evoke rejection or disapproval in representatives of another culture, and can cause tensionin communication. As a result, there may be misunderstanding between the communicants or one of the interlocutors may have an unfavorable impression of the other (in Japanese culture sitting with your legs crossed or stretched is considered inappropriate; for the British, it is a behavioral norm); communicating may be in a state of "cultural shock" [4, p. 156-158].

It can be inferred from the article that: 1) the main feature of stereotypes is their cultural determinism - a person's ideas about the world are formed under the influence of the cultural environment in which he/she lives; 2) stereotypes are shared by most people, but they can vary depending on the historical, international, as well as the domestic political situation in the country; 3) stereotype is a relatively stable, generalized image or a series of traits (often false), which, by and large, are characteristic of representatives of their own cultural and linguistic community, or representatives of other nations; 4) in the process of perceiving ethnic-specific stereotypes we form a certain attitude towards them, mostly they are perceived as something alien; thus a conflict of cultures arises; it results in discrepancies accepted in one's own culture, which is alien to the recipient; 5) the clash of stereotypes characteristic of different cultures can bring about difficulties in communication, cause "cultural shock" and, thus, lead to misunderstandings.

\section{References:}

1. Анохіна T.O. Lacunae in Terms of Scholars: the Brief Overview. Філологічні трактати. 2015. № 1. Т. 7. С. 7-11.

2. Ерофеев Н.А. Туманный Альбион: Англия и англичане глазами русских, 1825-1853 гг. Москва : Наука, 1982. 320 с

3. Кон И.С. К проблеме национального характера. Москва, 200. $167 \mathrm{c}$.

4. Леонтьев А.А., Тарасов Е.Ф. Национально-культурная специфика речевого поведения. Москва : Наука, 2007. 352 с.

5. Мальцева Д.Г. Германия: страна и язык. Лингвострановедческий словарь. Москва : Астрель, 2001. 416 с.

6. Марковина И.Ю. Психологические и социально-психологические механизмы культурологической лакунизации. Вопросы психолингвистики. 2010. № 1(11). С. 32-41.

7. Павловская А.В. Этнические стереотипы в свете межкультурной коммуникации. Вестник МГУ. Сер. 19. Лингвистика и межкультурная коммуникация. 1998. № 1. С. 94-104.

8. Сорокин Ю.А., Марковина И.Ю. Опыт систематизации лингвистических и культурологических лакун: Методологические и методические аспекты. Лексические единицы и организация структуры литературного текста : сборник науч. тр. Калинин, 1983. C. $35-52$.

9. Томашева И.В. Понятие “лакуна” в современной лингвистике. Эмотивные лакуны. Язык и эмоции. Волгоград : Перемена, 1995. C. 50-60.

10. Филиппова М.М. Парадоксы и стереотипы межкультурного общения представителей русской и британской культур. Вестник МГУ. Сер. 9. Филология. 2002. № 3. С. 64-82.

11. Andersen, P., Andersen, J. "Measurements of Perceived Nonverbal Immediacy". The sourcebook of nonverbal measures: Going beyond words, edited by Valerie Manusov. Lawrence Erlbaum Associates Publishers, 2005. P. 113-126.

12. Buchanan, W., Cantril, H. How Nations See Each Other. Urbana, 1953.

13. Grodzki, E. M. Using Lacuna Theory to Detect Cultural Differences in American and German Automotive Advertising. Peter Lang, Frankfurt on Main, 2003. P. 109-161.

14. Cuddy, A. J., Fiske, S., Kwan, V., Glick, P., Demoulin, S. "Stereotype content model across cultures: Towards universal similarities and some differences". British Journal of Social Psychology, 48, 2009. P. 1-33. UPL: https://doi:10.1348/014466608X314935 (дата звернення: 13.01.2020).

15. Dashidorzhieva, B. Types of Lacunae in Intercultural Communication. Заочные электронные конференции, August 22, 2011. URL: http:// www.econf.rae.ru/, data retrieved on 8 January 2014 (дата звернення: 13.01.2020).

16. Hornby, A.S. Oxford Advanced Dictionary of Current English. $9^{\text {th }}$ edition Oxford University Press, 2016. 1905 p.

17. Kashima, Y., Fiedler, K., and Freytag, P. Stereotype dynamics: Language-based approaches to the formation, maintenance, and transformation of stereotypes. New York, NY : Lawrence Erlbaum, 2008. $143 \mathrm{p}$.

18. Katz D., Braly K. Racial Stereotypes in One Hundred College Students. Journal of Abnormal and Social Psychology. 1933. Vol. 28. 305 p.

19. Lee, T., Fiske, S. Not an out-group, not yet an in-group: Immigrants in the stereotype content model. International Journal of Intercultural Relations, no. 30, 2006: 751-768. URL: https://doi:10.1016/j. ijintrel.2006.06.005 (дата звернення: 15.12.2018).

20. Lippman Walter. Public Opinion. New York, 1950. 294 p.

21. Peabody, D. National Characteristics. New York: Cambridge University Press.1985. P. 96-97.

22. Vundt, W. Problemi psikholohii narodov. Akademicheskii proekt, 2010. $136 \mathrm{c}$.

23. Wierzbicka, A. A conceptual basis for intercultural pragmatics and world-wide understanding. Developing Contrastive Pragmatics: Interlanguage and Cross-Cultural Perspectives, edited by Martin Putz \& JoAnne Neff-van Aertselaer. Mouton de Gruyter, Berlin, 2008. P. $3-45$.

24. The Longman Dictionary of English Language and Culture. Addison Wesley Longman, Pearson Education Limited, 2008. 1620 p.

Аксютіна Т.В., Алексєєв В.С. До аналізу етнокультурних лакун у контексті міжкультурної комунікації

Анотація. У статті досліджено поняття «етнокультурний стереотип» 3 огляду на теоретичні бачення науковців, яке подається як культурна домінанта, що існує у свідомості їі носіїв ментальною картинкою, наділеною специфічними властивостями, певним усталеним, мінімізовано інваріантним, зумовленим національно-культурною специфікою уявленням про предмет або ситуацію, що формує національно-культурне середовище, а також специфіку мовленнєвої діяльності їі представників. Проаналізовано особливості зображення національної культури в стереотипах.

3 дослідження стає зрозумілим, що у процесі сприйняття стереотипів культури іншого народу формується певне до них ставлення. Найчастіше вони сприймаються як щось чуже, адже, відкриваючи для себе нову культуру, реципієнт оцінює іiі крізь призму прийнятих у рідному лінгвосоціумі культурних норм і цінностей, що зумовлено особливостями кожної з мов. Суперечності та розбіжності у сприйнятті навколишнього світу носіями різних мов призводять до конфлікту культур. Зіткнення характерних для різних культур стереотипів (конфлікт культур) може 
створити труднощі у спілкуванні, стати причиною «культурного шоку» i, таким чином, призвести до нерозуміння культури іншого народу.

У статті докладно розглянуто особливий тип стереотипів - етнокультурні лакуни, що $є$ базовими елементами національної специфіки лінгвокультурної спільноти, які фіксують комплекс розбіжностей у мовах і культуpax, що контактують. У процесі міжкультурної комунікації «образи» культур, що несуть у собі інваріантні та варіантні складники, зіставляються та/або приймаються, або відштовхуються, що ускладнює розуміння реципієнтом іншої культури й вимагає додаткового пояснення. Зосереджено увагу на функціонуванні культурно-специфічних елементів у міжмовному дискурсі та пов'язаних із ними семантичних прогалинах у концептосферах комунікантів, визначено способи подолання подібних розбіжностей у лінгвокультурних досвідах мовних спільнот.

Ключові слова: стереотип, національний характер, міжкультурна комунікація, етнокультурні лакуни, культурний шок. 